\title{
SACROCOCCYGEAL CHORDOMA IN A 9-YEAR-OLD BOY
}

\author{
LUCIA DE NORONHA *, BETINA WERNER*, CARMEM MARIA C. MENDONGA**, \\ LUIZ NOMURA ** , LUIZ FERNANDO BLEGGI-TORRES*
}

\begin{abstract}
SUMMARY - A case of sacrococcygeal chordoma in a 9-year-old boy is presented. The symptoms at presentation were pain in both legs and sacrococcygeal region for the last two years that increased in the last four weeks irradiating mainly to the left leg. X-ray and CT scan examinations of the lumbar region revealed an expansive process in the coccygeal region with multiple calcifications and a partially eroded coccyx. There was no invasion of the retroperitoneum and regional lymph nodes. A biopsy was performed and showed cords and nests of cells with large cytoplasm, sometimes vacuolated, nuclei with moderate pleomorphism and clumped chromatin. Immunohistochemistry with avidin-biotin peroxidase technique showed positivity for CK, S-100 protein, CEA, vimentin and to EMA. Chordomas are a distinctly uncommon neoplasm in the first two decades of life, specially in the sacrococcygeal region. They have an aggressive behavior. Treatment of choice is complete resection.
\end{abstract}

KEY WORDS: chordoma, immunohistochemistry, notochord, bone tumors.

\section{Cordoma sacrococígeo em um menino de 9 anos de idade}

RESUMO - Os autores apresentam um caso de cordoma sacroccígeo $\mathrm{em}$ um menino de 9 anos de idade. $O$ paciente foi admitido no hospital com história de dor na região sacral e nos membros inferiores com dois anos de evolução, piorando nas últimas quatro semanas. O exame físico revelou atrofia muscular moderada $\mathrm{em}$ ambos os membros inferiores, diminuição do reflexo patelar e presença do sinal de Lasègue à esquerda. Os exames de imagem da região lombar mostraram um processo expansivo na região sacrococcígea com erosão parcial do coccix e focos de calcificaçāo, sem evidência de metástases para linfonodos regionais. Foi realizada biópsia diagnóstica que mostrou neoplasia formada por cordões e ninhos de células de citoplasma amplo, por vezes vacuolado, com núcleos moderadamente pleomórficos com cromatina grumosa. $O$ estudo imunohistoquímico revelou positividade para CK, proteína S-100, CEA, vimentina e EMA. Cordornas são tumores raros que representam em torno de $2 \%$ de todas as neoplasias malignas do osso. Os locais de maior acometimento são as extremidades da coluna espinhal e são incomuns nas primeiras duas décadas de vida, especialmente na regiāo sacrococcígea.

PALAVRAS-CHAVE: cordoma, imuno-histoquímica, notocorda, tumores ósseos.

Chordomas are rare slow-growing tumors that represent around $2 \%$ to $5 \%$ of all malignant tumors of bones ${ }^{25}$. They derive from ectopic notochordal remnants along the axial skeleton at any location from the base of the skull to the sacrococcygeal region? They have aggressive behavior with local invasion of bone and surrounding tissues ${ }^{11}$. Chordoma is distinctly uncommon in patients under 30 years of age and has a peak incidence around the sixth decade ${ }^{13}$. Less then $5 \%$ of cases are diagnosed before 20 years of age $\mathrm{e}^{3}$. Although the sacrococcygeal region is the most frequent site in adults, tumors arising in the base of the skull appear to predominate in children ${ }^{3,13}$.

* Section of Neuropathology and Electron Microscopy and ** Department of Pediatrics, Hospital de Clínicas, University of Paraná; *** Hospital Nossa Senhora das Graças, Curitiba. Aceite: 5-maio-1995.

Luiz F. Bleggi Torres, M.D., Ph.D. - Seção de Neuropatologia e Microscopia Eletrônica, Departamento de Patologia, Hospital das Clínicas - Rua General Carneiro 181 - 80060-900 Curitiba PR - Brasil. 
The present report deals with a case of chordoma affecting the sacrococcygeal region in a nine-year-old boy. As far as we concern no previous similar report has been found in the Brazilian literature.

\section{CASE REPORT}

$\mathrm{MB}$, a 9-year-old boy was admitted to hospital presenting pain in both legs and sacrococcygeal region for the last two years. The patient related that this pain increased in the last four weeks irradiating mainly to the left leg. Physical examination revealed moderate muscular atrophy in both legs, diminished patellar reflex and pain during flexion of the left leg. X-Ray examination of the lumbar region revealed multiple calcifications and a partially eroded coccyx. CT scan (Fig 1) showed an expansive process in the coccygeal region. There was no invasion of the retroperitoneum and regional lymph nodes. A biopsy was performed and showed cords and nests of cells with large cytoplasm, sometimes vacuolated, nuclei with moderate pleomorphism and clumped chromatin (Fig 2A, 2B and 2C). These cells were immersed in a myxoid background. Immunohistochemestry with avidin-biotin peroxidase technique showed positivity for CK (cytokeratin), S-100 protein, CEA (carcinoembryonic antigen), vimentin and to EMA (epithelial membrane antigen) (Fig 2D). The results confirmed the diagnosis of chordoma, classical type, showing significant atypia and foci of necrosis which suggest aggressive behavior.

\section{COMMENTS}

The notochord is a embryological structure around which the axial skeleton and skull are formed. Luschka and Virchow, in the 19th century, were the first to notice notochordal remnants in adults. Later, Müller also realized that portions of the notochord persisted after birth in a number of different sites giving rise to small masses of cells that he called ecchordoses physaliphora. The similarity between the cells of chordomas and those cells was then recognized by Ribbert ${ }^{10,11}$.

The majority of chordomas arise at the ends of the spinal column 1-3.5.7.9.11-13. The pathogenesis of chordoma remains unclear since regression and atrophy are expected to occur as a uniform process along the length of the rod-like notochord. According to Salisbury and co-workers ${ }^{11}$, the rostral and caudal parts of the notochord are complicated structures with forking of the ends and with fragments

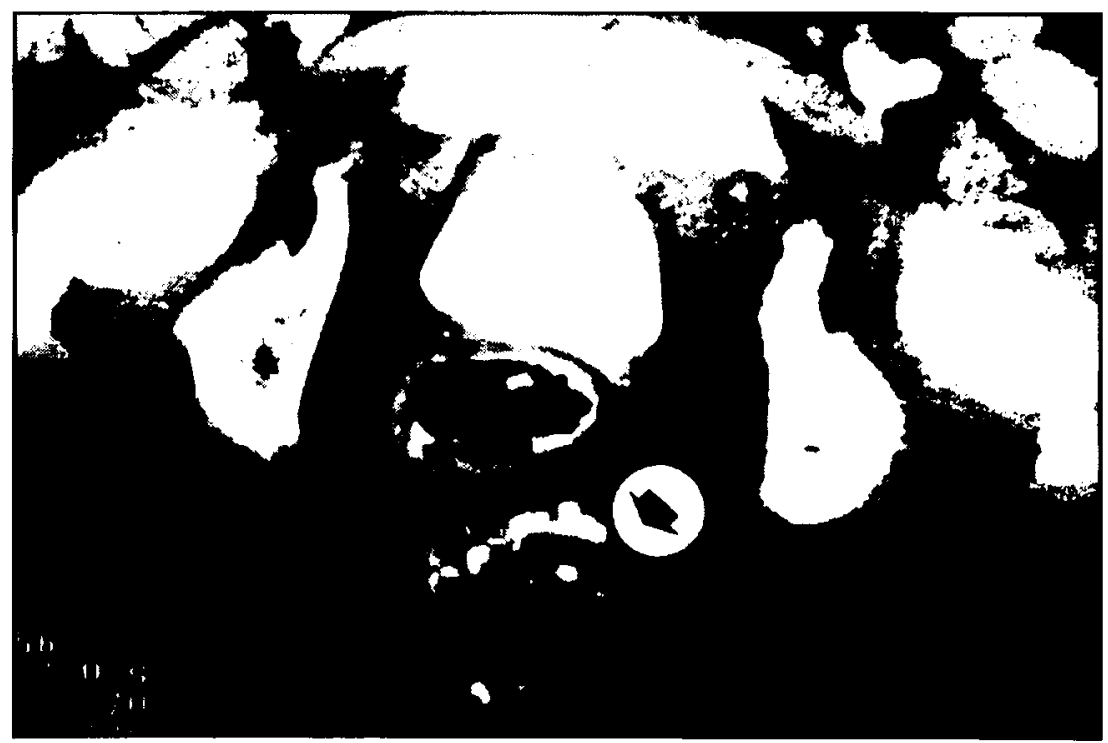

Fig J. CT scan of sacrococcygeal region showing bone destruction with foci of abnormal calcification of coccyx (arrow). 


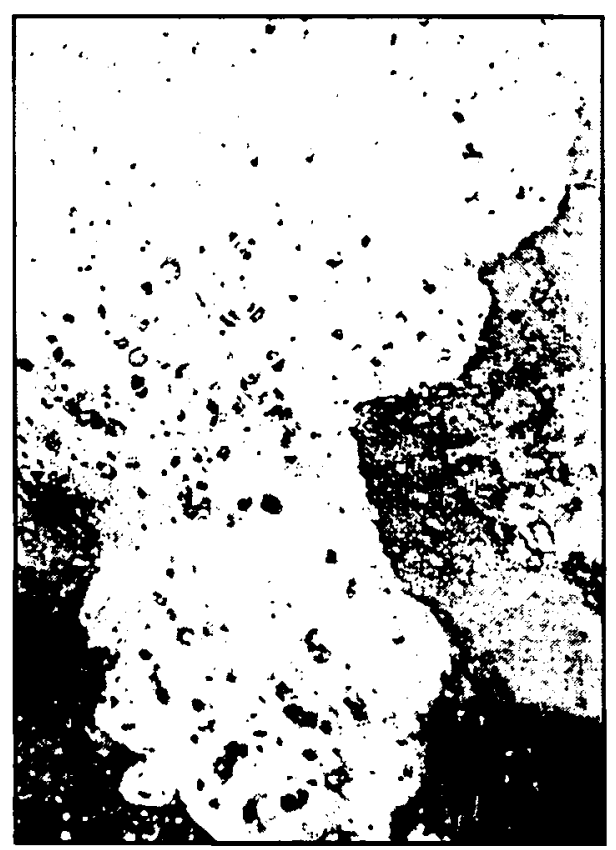

Fig 2A. Low power view of chordoma infiltrating bone (arrows).

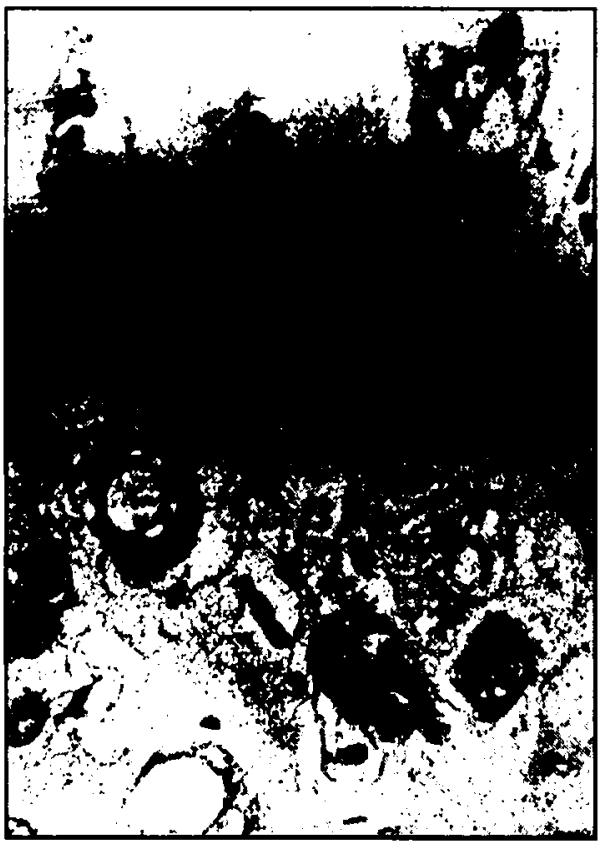

Fig 2C. Area with highly pleomorphic chordomatous cells.

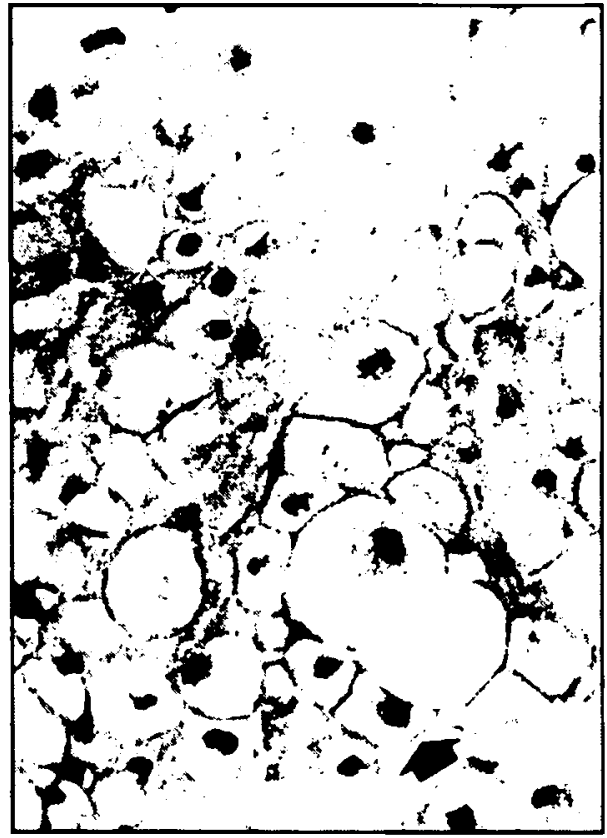

Fig 2B. Chordoma cells with large vacuolated cytoplasm and small nuclei. Occasional phisaliferous cells are present (arrow).

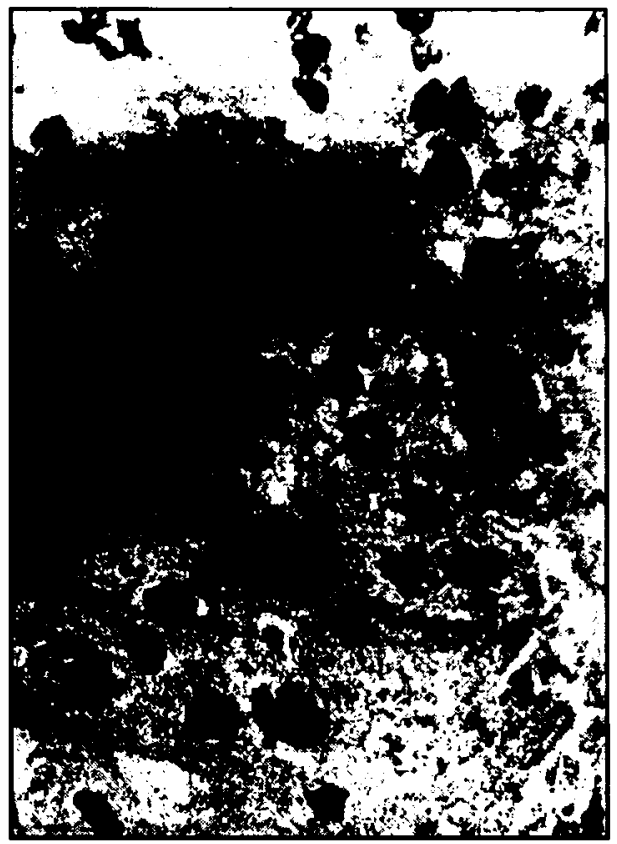

Fig 2D. Immunohistochemistry for cytokeratin (AEI) showing intense positivity in tumor cells. 
of chordal tissue separated from the main part. It becomes possible then to envisage how a regressive or atrophic process confined to the main structure could leave behind collections of notochordal cells in the spheno-occipital and sacral regions.

The clinical findings at presentation of sacrococcygeal tumors are vague back pain of long duration, lower-extremity pain and immobility, local mass, bladder or bowel dysfunction and history of significant trauma to the sacrum ${ }^{3.5 .7 .9}$. The duration of symptoms before operation or biopsy ranges from 1 month to 6 years ${ }^{2,59}$. The usual X-ray and CT scan appearance of all chordomas are a lytic, expansive and destructive large masses ${ }^{5.7}$.

Chordomas are nodular, cystic or gelatinous masses with dense fibrous surrounding bands, measuring from 1 to $10 \mathrm{~cm}$. A pushing margin can be seen associated with osteolysis and replacement of bone by diffuse tumor infiltration ${ }^{2,9}$. Fresh specimens have been described as having a deep reddish or purple color and may contain hemorrhagic areas ${ }^{9}$.

Chordomas can be divided into three distinct, but often overlapping, types: classic or conventional, chondroid and those with a malignant spindle cell component ${ }^{4}$. The first type is characterized by cells arranged in chords embedded in abundant mucinous matrix admixed with physaliferous cells. Chondroid chordomas have a significant cartilaginous component. This seems to be the least aggressive type, usually following a relatively indolent course $e^{4.9 .13}$. The last type of chordoma is characterized by the presence of a significant atypical spindle cell component intermixed or associated with areas of conventional chordoma. The spindle cell component in these neoplasms is highly cellular, pleomorphic and with a high mitotic rate. This type behaves in an aggressive manner and often metastasizes ${ }^{4}$. Some authors mention that variations in histologic pattern do not affect the biologic behavior of the tumor ${ }^{2.5 .9}$.

Differential diagnosis must be made with chondromas, chondrosarcomas, muscinous carcinoma and ependymoma ${ }^{1,12}$. Immunohistochemistry is the method of choice in achieving differentiation between chordomas and those tumors. Our case was positive for CK, EMA, vimetin and S-100 protein and these results are similar to those reported in the literature ${ }^{1,6,6,12}$. It also was positive to CEA, which is a controversial finding ${ }^{13,8,12}$.

Total extirpation when technically feasible offers the best chance for cure ${ }^{5,9}$. Keisch et al suggest postoperative radiation ${ }^{7}$. The goal of treatment must be complete surgical resection, avoiding violation of tumor, so that disease-frec margins can be achieved ${ }^{5}$. This is the most important factor in reducing recurrences which are estimated in $25 \%$.

The survival rate ranges from 30 to $76 \%$ in five years ${ }^{6.7 .9}$. The incidence of metastasis varies from 18 to $45 \%$ and only occurs later in the course of disease, mainly in large sized sacrococcygeal tumors ${ }^{2.5 .6 .9}$. Metastases are found in bones, lymph nodes, brain, lungs and abdominal viscera ${ }^{y}$. Chordomas in early childhood may have a tendency to grow more rapidly and to metastasize more frequently than those in adults ${ }^{3,6}$.

\section{REFERENCES}

1. Abenoza P, Sibley RK. Chordoma: an immunohistologic study. Hum Pathol 1986; 17:744-747.

2. Bjornsson J, Wold LE, Ebersold MJ, Laws ER. Chordoma of the mobile spine: a clinicopathologic analysis of 40 patients. Cancer 1993; 71:735-740.

3. Coffin CM, Swanson PE, Wick MR, Dehner LP. Chordoma in childhood and adolescence: a clinicopathologic analysis of 12 cases. Arch Pathol Lab Med 1993; 117:927-933.

4. Hruban RH, Traganos F, Reuter VE, Huvos AG. Chordomas with malignant cell components: a DNA flow cytometric and immunohistochemical study with histogenetic implications. Am J Pathol 1990; 137:435-447.

5. Kaiser TE, Pritchard DJ, Unni KK. Clinicopathologic study of sacrococcygeal chordoma. Cancer 1984; 54:2574-2578. 
6. Kaneko Y, Sato Y, Iwaki T, Shin RW, Tateishi J, Fukui M. Chordoma in early childhood: a clinicopathological study. Neurosurgery $1991 ; 29: 442-446$.

7. Keisch ME, Garcia DM, Shibuya RB. Retrospective long-term follow-up analysis in 21 patients with chordomas of various sites treated at a single institution. J-Neurosurg 1991; 75:374-377.

8. Miettinen $M$. Chordoma: antibodies to epithelial membrane antigen and carcinoembryonic antigen in differential diagnosis. Arch Pathol Lab Med 1984; 108:891-895.

9. Rich TA, Schiller A, Suit HD, Mankin MJ. Clinical and pathological review of $\mathbf{4 8}$ cases of chordoma. Cancer 1985; 56:182-187.

10. Salisbury JR. The patology of the human notochord. J Pathol 1993; 171:253-255.

11. Salisbury JR, Deverell MH, Cookson MJ, Whimster WF. Three-dimensional reconstruction of human embryonic notochords: clue to the pathogenesis of chordoma. J Pathol 1993; 171:59-62.

12. Walaas L, Kindblom LG. Fine-needle aspiration biopsy in the preoperative diagnosis of chordoma: a study of 17 cases with application of electron microscopic, histochemical and immunocytochemical examination. Hum Pathol 1991; 22:22-28.

13. Wold LE, Laws ER. Cranial chordomas in children and young adults. J Neurosurg 1983; 59:1043-1047. 